\title{
Prospects for the development of Mongolia's Coal export
}

\author{
A.D. Sokolov ${ }^{1}$, L.N. Takaishvilii ${ }^{1}$, O. Punsalmaagiin ${ }^{2}$
}

\begin{abstract}
${ }^{1}$ Melentiev Energy Systems Institute of Siberian Branch of Russian Academy of Sciences, Irkutsk, Russia
${ }^{2}$ University of Geology and Mining of the Mongolian Science and Technology, Ulaanbaatar, Mongolia
\end{abstract}

\begin{abstract}
In recent years, Mongolian coal export has grown and gained great importance for the country. The significant resources of high-quality coal and demand for coal in the international market contribute to the augmentation of Mongolian coal export. The expanding coal supplies to the international market affect greatly the development of coal mining in Mongolia. The paper presents the status of coal resources and the characteristics of the most ambitious projects for the development of coal export. The most significant coal development projects are mainly related to the development of deposits in the South Gobi region. Foreign companies that hold licenses for the development of deposits take part in the development of coal deposits. Current and potential future restrictions on the development of coal export are given. The main of them are the lack of access to the seacoast, as Mongolia is a landlocked country; state of transportation infrastructure; the availability of resources for the development of production, and the geopolitical conditions affecting the demand for coal in the world market. Coal exports can be delivered to the international market from the seaports of China and Russia, through the territories of these countries. Further increase in coal export from Mongolia depends on the development of transportation and production infrastructures; the situation in the international coal market; the availability of resources for the development of deposits; and opportunities to increase the volume of exploration. In the future, Mongolia could become one of the world's major coal exporters.
\end{abstract}

Index Terms - Mongolia, coal, reserves, mining, projects, export, coal transportation.

\footnotetext{
${ }^{*}$ Corresponding author.

E-mail: scientist@domain.com
}

http://dx.doi.org/10.38028/esr.2020.01.0004

Received April 06, 2020. Revised May 10, 2020.

Accepted May 27, 2020. Available online July 31, 2020.

This is an open access article under a Creative Commons Attribution-NonCommercial 4.0 International License.

(C) 2020 ESI SB RAS and authors. All rights reserved.

\section{INTRODUCTION.}

The export of goods is of great importance for the economy of Mongolia. Fossil resources such as gold, coal, copper concentrate, zinc and iron ores, and crude oil account for more than $80 \%$ of exports $[1,2]$. Coal export is developing at the fastest pace and in recent years it has surpassed the export of other goods. The significant resources of high-quality coal $[3,4]$ and the growing demand for Mongolian coal in the international market create the prospects for increasing coal exports from Mongolia. According to international statistics [5], since 2016 Mongolia has been among the top ten countries in terms of coal export and in terms of export-to-production ratio. Mongolia is second only to Australia in per capita coal production. In 2016, Mongolia ranked 21st in coal production among the countries mining coal, and in 2018, it ranked 14th [6].

Currently, the main importer of Mongolian coal is China, the world's largest importer of coal. In 2018, small shipments of coal were delivered to Hong Kong and Great Britain. In 2018, coal exports accounted for $62 \%$ of the total coal production [2]. In 2015-2018, revenues from coal export increased by more than 100 times and amounted to about $\$ 2,800$ million in 2018 .

The main export markets for Mongolian coal intersect with the Russian ones. This is, first of all, China, importing both Russian and Mongolian coal. Japan, Korea, and other countries of Northeast Asia (NEA), importing Russian coal, are potential importers of Mongolian coal.

\section{A RETROSPECT OF COAL INDUSTRY DEVELOPMENT}

The dynamics of coal production and supply development is shown in Figure 1. The main increase in production is due to rising demand for coal in the international coal market, against the background of a stable, although an insignificant, increase in supplies for domestic consumption.

From 2005 to 2018, coal production increased almost by 7 times from 7.5 million tons to 51.4 million tons, while coal export rose by more than 15 times from 2.1 million tons to 32 million tons, and the supplies to the domestic market increased only by 1.7 times from 5.5 million tons to 9.5 million tons $[2,7]$.

The most important type of fuel in the domestic market 


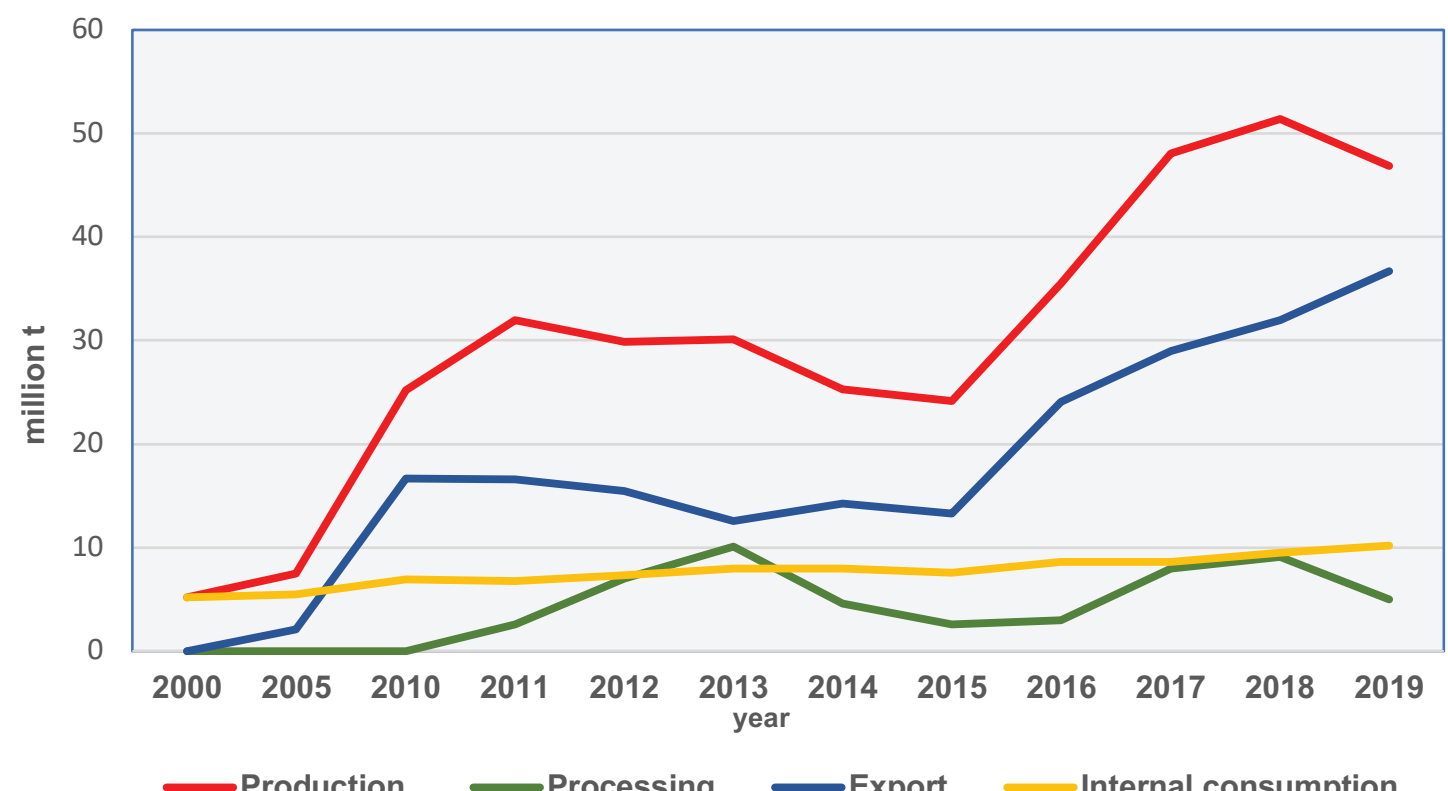

Fig. 1. - Indices of coal production and supplies. Source: [2].

in Mongolia is coal [8.9]. Coal reserves significantly exceed those of oil and gas. The share of coal in the consumption of primary energy resources in retrospect ranged from 60 to $80 \%$ [10]. The main consumers of coal in Mongolia are power plants. Coal consumption by power plants accounts for about $80 \%$ of the total coal supplies to the domestic market.

Coal is mined by both state and private enterprises. Coal mining by state-owned enterprises increased by more than three times in 2005 - 2018 (from 4.5 to 16.5 million tons), and the amount of coal mined by private enterprises rose by more than 10 times (from 3, 1 to 34.9 million tons). The share of exports in deliveries also increased from $28 \%$ in 2005 to $77 \%$ in 2018 . Coal is exported mainly by private companies. Mainly coking coal is exported, both washed and unwashed. The share of coking coal in export deliveries is about $70 \%$. The supply of Mongolian coal to China is gradually replacing coal supplies from Russia, Canada, Australia, and the United States. The price of Mongolian coal on the border with China in January 2018 was $\$ 65.5$ - 70.5 per ton, which allows Mongolia to compete with coal exporters to NEA countries, i.e. Russia, Australia, Indonesia, Canada, and others. [11].

\section{COAL RESOURCES FOR EXPORT}

The coal resources of Mongolia are estimated at 173.5 billion tons, and the explored reserves of the $\mathrm{A}+\mathrm{B}+\mathrm{C} 1$ categories are 33.1 billion tons as of 1.01 .2020 [5, 7]. There are deposits and manifestations of coal in almost all areas of the country. The ratio of reserves to resources for different coal basins ranges from 0 to $30 \%$, on average - $18 \%$, which indicates a low degree of exploration of deposits. Of the 15 coal basins, the most studied ones are the South Gobi (hard coal) and Choyr-Nyalga (brown coal). For the development of coal export, the most attractive deposits are the deposits of coking and high-quality steam coal, mainly in two areas: the southern (South Gobi and South Hangai basins) and central (Choyr-Nyalga basin). The southern area is characterized by a semi-desert climate, lack of water supply, high-quality coal, and a small-scale of coal mining for local needs. Most of the coal mined in the area is exported. The central area is characterized by

Table 1. Coal mining development projects for coal export

\begin{tabular}{|c|c|c|c|c|c|c|}
\hline Deposit & $\begin{array}{l}\text { Coal } \\
\text { reserves, } \\
\text { million } \mathrm{t}\end{array}$ & $\begin{array}{l}\text { Thickness of } \\
\text { seams, } \mathrm{m}\end{array}$ & $\begin{array}{l}\text { Potential } \\
\text { production, } \\
\text { million } \mathrm{t}\end{array}$ & $\begin{array}{l}\text { Year of } \\
\text { commissioning }\end{array}$ & $\begin{array}{l}\text { Volume of } \\
\text { production in } \\
2019, \text { million } \mathrm{t}\end{array}$ & $\begin{array}{l}\text { The state of the infrastructure at the } \\
\text { beginning of the project: the road to the } \\
\text { nearest border crossing; power source }\end{array}$ \\
\hline Tavan Tolgoi & 1600 & $2-86,2$ & $15-20$ & $\begin{array}{l}1966 * \\
2010 / 2013\end{array}$ & 16,5 & $\begin{array}{l}254 \mathrm{~km} \text {; central grid and diesel power } \\
\text { plants }\end{array}$ \\
\hline Ukhaan Khudag & 505 & $30-60$ & 15 & 2009 & 10,0 & $\begin{array}{l}245 \mathrm{~km} \text {; central electric grid and power } \\
\text { plant with a capacity of } 18 \mathrm{MW} \text {. }\end{array}$ \\
\hline Ovoot Tolgoi & 302 & 35 & 9 & 2008 & 5,0 & $\begin{array}{l}44.8 \mathrm{~km} \text {; electric grid of China and } \\
\text { diesel generator }\end{array}$ \\
\hline Nariin Sukhait & 587.5 & 53,8 & 14 & 2008 & 3,6 & $44.8 \mathrm{~km}$; electric grid of China \\
\hline Khoshoot & 300 & 40,0 & 3 & 2011 & 3,6 & $310 \mathrm{~km}$; diesel power plant \\
\hline
\end{tabular}

* western section with reserves of 218.7 million t. Source: [12-15]. 
stable mining and geological conditions, and large-scale coal mining for domestic consumption.

Most deposits are suitable for open-pit mining. The depth of bedding is from 200 to $500 \mathrm{~m}$, and only for the Tavan Tolgoi deposit, it is up to $1000 \mathrm{~m}$, and the thickness of seams varies from 2 to $100 \mathrm{~m}$. Coals of the largest deposits are characterized by high quality, medium ash content (8.7$20.9 \%$ ), low sulfur content $(0.3-0.8 \%)$, and a sufficiently high calorific value [9]. The main projects for increasing coal exports are presented in the 2016 annual report of the Ministry of Mining of Mongolia [12]. Table 2 shows the projects for which the coal reserves of the developed deposits exceed 100 million tons. The presented deposits are situated in the south of Mongolia (the Khoshoot deposit is in the coal basin of South Khangai, and the rest of the deposits are in the coal basin of the South Gobi). The deposits have reserves of coking and high-quality steam coal. Mining and geological conditions for the development of deposits are mostly favorable. The deposits are suitable for open-pit mining. There are coal processing facilities at the Ukhaa Khudag and Khoshoot deposits. Transportation infrastructure is poorly developed. The operating life of the Tavan-Tolgoi deposits is more than 200 years, and that of the rest of the deposits is 40-50 years in terms of 2018 production levels.

Multinational companies from leading developed countries, which are deficient in coking coals, show an increased interest in promising deposits, primarily China. The licenses for the development of the presented coal deposits are partially or fully owned by foreign companies; international organizations take part in funding the projects. Mongolian companies are also involved in the development of the deposits.

The most significant projects are the development of Ovoot Tolgoi and Tavan Tolgoi deposits. Tavan Tolgoi is the world's largest and most promising deposit.

The Ovoot Tolgoi high-quality coking coal deposit is located at a distance of $46 \mathrm{~km}$ from the border with China. About $90 \%$ of coal reserves are suitable for open-pit mining. SouthGobi Resources Ltd., a Canadian company, has a license to develop more than $80 \%$ of the deposit.

The Tavan Tolgoi deposit is located in the South Gobi region, at an altitude of 1500-1830 meters above sea level, at a distance of 50-270 km from the border with China. The deposit has the reserves of high-quality coking and steam coal, including scarce grades (K, KZh, Zh). The project suggests the construction of processing plants, a coal-fired power plant, and a $70 \mathrm{~km}$ pipeline for water supply. In the future, production and processing at two coal washing plants may amount to 30 million tons per year. Mining has been performed at the site of the Western Tsanghi deposit since 1967. The coal mined was supplied to the domestic market of Mongolia. Erdenes TavanTolgoi (ETT), a Ulan Bator company, currently holds the licenses for the deposit development. Apart from the deposit development, foreign companies are planning to build a 400-kilometer railway line from Tavan Tolgoi to the city of Sai-shand adjacent to the existing Ulan-Bator railway network (UBRN), modernize it and use the port facilities of Siberian Coal Energy Company in the Far East.

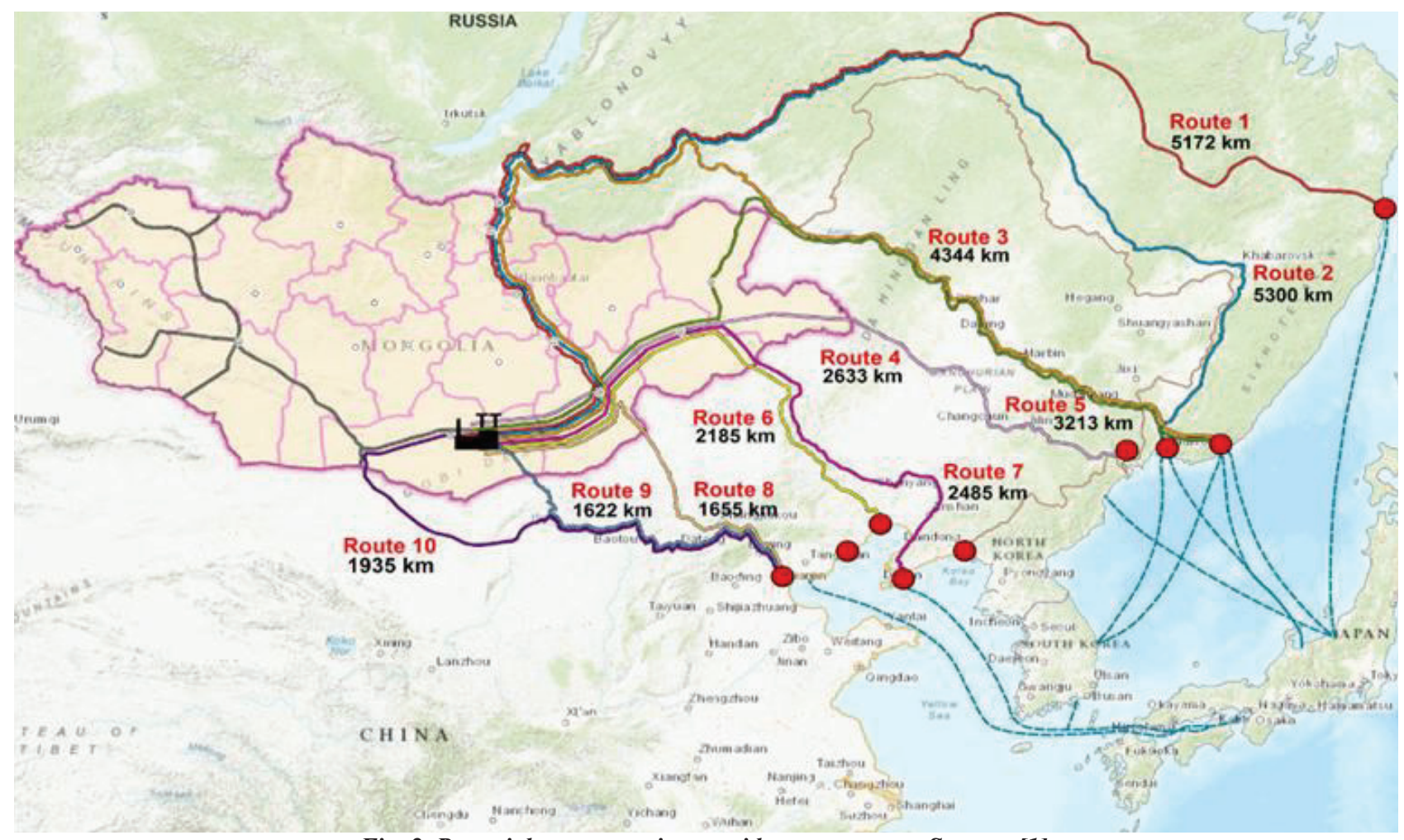

Fig. 2. Potential transportation corridors to seaports. Source: [1]. 
In addition to the projects presented, there are also smaller-scale projects and projects for the development of steam coal deposits, both for domestic consumption and for export. Implementation of the projects involves building transportation infrastructure and supplying electricity, water, and other resources. The timing of project implementation depends on the implementation of these activities, the availability of investments, and the situation in the global coal market.

\section{POSSIBLE RESTRICTIONS ON THE DEVELOPMENT OF COAL EXPORTS FROM MONGOLIA}

In addition to favorable conditions for the development of Mongolian coal export such as the available reserves of high-quality coal, which is in demand at the international market, there are also certain restrictions. The main restrictions are connected with the lack of access to the seacoast, poor development of internal transportation infrastructure, the availability of resources for the development of deposits, geopolitical, and other conditions.

\section{Lack of access to the seacoast}

Mongolia is a landlocked country that does not have access to the seacoast. It borders two giant neighbors Russia and China. Currently, about $99 \%$ of coal is exported to China.

There are two possible directions of deliveries to the international market: either through the territory of China or through the territory of Russia to seaports. Multilateral cooperation with Russia and China is necessary, to provide transit traffic through the territories of these states to seaports. This creates Mongolia's dependence on the policies of Russia and China, through which Mongolian coal can be delivered to the international market. Possible transportation corridors are to the border with Russia or China and further along the territory of Russia to the fareastern ports, or through China to the nearest ports (Fig. 1) $[1,16]$.

The most promising coal deposits suitable for export are located in the south of Mongolia, quite close to the Chinese border. The distance from coal mining enterprises on paved roads to the major crossings on the border with China ranges from 45 to $310 \mathrm{~km}$ [9]. From a logistics point of view, it would be most rational to supply coal to NEA markets through China. China has high-capacity port coal terminals Qinhuangdao (cargo turnover of 226.4 million tons/year) and Tianjin (100 million tons/year) - according to SCEC and the Coal Industrial Company [18]. The difficulties for the development of this supply chain are due to the interest of Chinese entrepreneurs in buying coal at low prices on the Mongolian border and then reselling it to the international market.

The transportation of Mongolian coal through the territory of Russia is complicated by competition between Mongolian and Russian coal mining companies that supply coal to the countries of NEA. Russian ports largely control coal companies that supply coal to potential importers of Mongolian coal. There are also restrictions on the throughput capacity of Russian railways and the capacity of Russian coal terminals in shipping ports in eastern Russia (less than 25 million tons/year for each of the coal terminals in the Vostochny and Vanino ports, which in total is almost by 7 times less than the Chinese terminals). It is planned to modernize the capacities of coal terminals and build new ones but the increase in the throughput capacity of the Russian railways does not keep pace with the growing demand for transportation of cargos.

A research team of the International Bank for Reconstruction and Development [19] estimated the total costs of coal mining and coal railway transportation. The calculations were performed for various potential rail routes for deliveries of coal from the Tavan-Tolgoi deposit to Russian and Chinese ports, depending on the annual volume of coal production. Seven routes were considered, three to Chinese ports and four to Russian. According to the calculation results, the costs of extraction and transportation to Russian Far-Eastern ports exceed the costs of transportation to Chinese ports by 1.5-2 times. The calculations were made under the assumption that all coal mined is transported by this route, the actual transportation prices can be higher and they can be determined by commercial agreements. A similar analysis was carried out for potential rail routes for coal transportation from Nariin Sukhait.

\section{Transportation infrastructure of Mongolia}

The transportation infrastructure of Mongolia is characterized by weak spatial and structural ties; significant distances between existing transportation junctions; extreme environmental conditions; poor technical equipment of roads; low density of roads in general and roads with the hard and improved pavement, in particular [20].

The main railway of the country connecting Ulan Bator with Russia and China, and thereby East Asia with Europe, is the Ulan Bator Railway (UBR). It provides domestic and transit transportation of cargos in Mongolia. UBR is of great strategic importance not only for Mongolia but also for the Russian Federation and China. At present, the operational length of the Mongolian railways is more than $1800 \mathrm{~km}$ [21]. It accounts for over $80 \%$ of all freight and passenger transportation in the country. UBR was built shortly after the end of World War II and now it is operating at the limit of its possibilities. The carrying capacity of the line is 25 million tons per year [22], which is less than the weight of exported goods. The total volume of cargo transported by UBR is constantly growing [2]. In 2018 , the volume of traffic on the UBR increased by $8 \%$ compared to 2017 and amounted to 24.5 million tons. At the same time, transit and import traffic rose by $27 \%$. By 2030, freight traffic is expected to increase further and reach 50 million tons $[23,24]$. 


\section{RAILWAY PROJECTS PLANNED FOR 2016-2020}

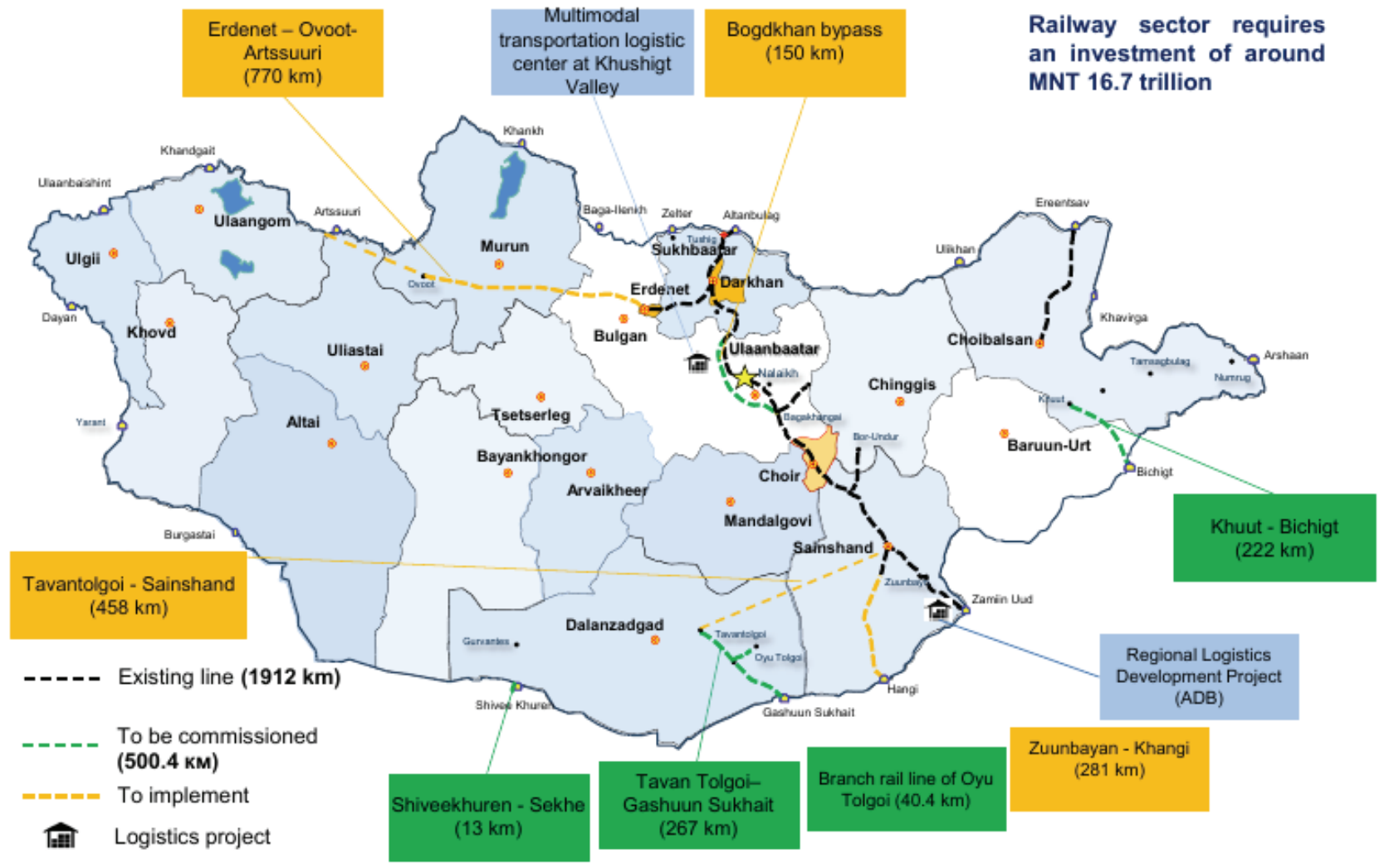

Fig. 3. Projects for the development of railway infrastructure. Source: [16].

Coal for domestic consumption is supplied by rail and road. Most of the coal for export is transported to the Chinese border by truck.

The need for transportation of increasing volumes of cargos creates the need for further development of transportation infrastructure, including UBR, and paved roads. Prospective export-oriented coal deposits do not have access to the main railway line. The development of the coal industry in Mongolia, focused on coal export, requires the development/modernization of existing railways and the construction of new ones. The strategic objectives for the development of Mongolian railways are presented in the document "Concept for the implementation of a joint Russian-Mongolian project for the development of JSC "UBR" and the construction of new railway infrastructure" [25]. The project involves the modernization of the existing network of JSC "UBR", as well as the construction of new railway lines connecting coal deposits and border crossings or/and UBR (Table 3, Fig. 2). The total length of these lines is 2.2 thousand $\mathrm{km}$.

Two railway options are considered to supply coal from the Tavan Tolgoi deposit: to the border crossing on the border with China (Tavan Tolgoi - Gashuun Sukhait) and with access to the main UBR line (Tavan Tolgoi-Zuunbayan). The second option opens the door for transporting Tavan Tolgoi coal both southward to China and northward to Russia and further to the Far-Eastern ports of Russia. The construction of this line is already underway.

Railway lines designed for the Tavan Tolgoi deposit can also serve the coal deposits of Ukhaa Khudag and Nariin Sukhait.

For the Ovoot Tolgoi deposit, located in the northwest of Mongolia, access to international markets is planned through the construction of the Erdenet-Ovoot-Artsuuri railway. The section of the future railway will have access to the Russian border in northern Mongolia and the UBR.

The study of the International Bank for Reconstruction and Development [19] gives the feasibility criteria for the construction of railway lines for coal export and their approximate cost. The construction of one kilometer of the railways is estimated at $\$ 1.8$ million and it will be economically viable only for the transportation volumes of at least 2-4 million tons per year. Most coal mining development projects meet this criterion.

International companies from Canada, Japan, China, and Russia (JSC "Russian Railways") participate in the development and implementation of the projects for building the transportation infrastructure in Mongolia to export coal. This, in addition to the construction and reconstruction of railways and dirt roads, entails the expansion of the throughput potential of border ports and transshipment points, the construction of a basic track structure, residential buildings, and administration buildings at some railway junctions. 
Table 2. Projects for construction of new railway lines. Source: [16].

\begin{tabular}{lcl}
\hline \hline \multicolumn{1}{c}{ Project } & Distance, $\mathrm{km}$ & \multicolumn{1}{c}{ Project status } \\
\hline Erdenet -Ovoot -Artsuuri & 770 & At the design stage \\
\hline Tavan Tolgoi-Zuunbayan (Sainshand) & 458 & Construction started in May 2019 \\
\hline Zuunbayan Khangi & 281 & Feasibility study is developed \\
\hline Tavan Tolgoi - Gashuun Sukhait & 267 & Construction work is in progress \\
\hline Khoot Bichigt & 222 & Feasibility study is approved, engineering design is made \\
\hline Bogdhan Bypass & 150 & Feasibility study is developed \\
\hline Oyu Railway & 40,4 & Engineering design is made \\
\hline \hline
\end{tabular}

\section{Resources for the development of deposits}

The development of coal mining is associated with the attraction of labor resources to the settlements closest to the mines. This also includes providing workers and their families with housing and related infrastructure. According to the estimates of the International Bank for Reconstruction and Development, the expansion of coal production at export-oriented coal deposits will require additional 80 thousand people, including about 17 thousand people for the Tavan Tolgoi and 33.5 thousand people for the Oyu Tolgoi. The amount of necessary investment in housing and infrastructure is estimated at $\$ 1.4$ billion. These data are already somewhat outdated but give an idea of the necessary resources.

The electricity and water supply to coal-mining enterprises and related settlements is very important. Most prospective deposits are located in the South Gobi region, which is scarce in water resources.

As for the electricity supply, the projects for the development of the deposits suggest providing electricity either through the construction of power plants on the coal of the deposit, or the reconstruction and expansion of the capacity of power plants operating in the settlements closest to the deposits under development, or through the export of electricity from China. The largest power plants are planned to be built at the Shivee Ovoo deposits, with a capacity of $5250 \mathrm{MW}$ and at the Tavan-Tolgoi deposit with a capacity of $600 \mathrm{MW}$. A coal-fired power plant at the Shivee Ovoo deposit is planned as part of the ChinaMongolia-Russia Economic Corridor project, with the prospect of electric power transmission to the PRC.

Initially, a diesel generator was used at the Tavan Tolgoi deposit. The commissioning of a $600 \mathrm{MW}$ power plant will ensure all types of activities in the Eastern and Western sections of the Tavan Tolgoi deposit, including a washing plant, and a system of water supply to the population and to the mines in the South Gobi region. The expected surplus power is planned to be transferred to the Mongolian network or China. Commissioning of the power plant is planned for 2023. The cost of the construction of the 600 MW power plant is estimated at $\$ 0.5$ billion [26].

\section{Geopolitical and other conditions}

According to forecasts made by international organizations, the prospects for coal consumption in the world are ambiguous and highly uncertain [27-30]. This is associated with the environment and climate policy of the countries, which is focused on measures intended to ensure low-carbon development, and as a result, to reduce coal consumption. Coal consumption is also affected by the possible slowdown or acceleration of economic growth in importing countries, primarily in China. According to the World Bank and the Russian Academy of Sciences, the Asian region consumes 75.7 percent of the world's coal, including 66 percent of it in China and India. (Source: World Bank, News of the Russian Academy of Sciences). NEA countries are potential importers of Mongolian coal. However, China remains the main importer of Mongolian coal. Growth in demand for imported coal is projected only in some NEA countries with a decrease in demand in China, the world's largest producer and consumer of coal. The demand for coal is projected to stabilize in South Korea, Japan, and Taiwan, while its growth is expected in India.

The factors restraining the growth of demand for coal in China are determined by internal policy on energy sources. These are reduction in energy-intensive production, accelerated development of new energy sources and advancements in the field of energy conservation, and unpredictable economic development conditions. As regards China's foreign policy, in retrospect, the growth of coal imports from Mongolia was affected by trade sanctions against North Korea, which were also imposed on coal imports.

The development of coal mining and the transportation system of Mongolia is largely dependent on foreign capital. A possible decrease in the interest of foreign investors caused by anti-investment laws and other factors can significantly affect the growth rate of coal production.

Thus, the development of Mongolian coal export depends not only on the energy prices at the world market but also on domestic and foreign policies of the countries importing coal, primarily China.

Other conditions include increased volumes of exploration, climatic conditions, and unpredictable events in the world.

Since Mongolia's coal reserves are poorly studied, an increase in the volume of exploration will allow identifying other coal deposits or areas of coal deposits that are promising for development. 
Climatic conditions are associated with the sharply continental climate of Mongolia: at certain times (mainly in the South Gobi basin), miners deal with temperatures that range from $-40^{\circ} \mathrm{C}$ to $+40^{\circ} \mathrm{C}$. This can limit some types of work compared to other regions where earthwork can be performed year-round [31].

The unpredictable events in the world, such as the fires in Australia, the epidemic of the coronavirus, the sanctions imposed by individual states, and similar global phenomena can slightly affect the demand for Mongolian coal.

Large-scale forest fires in Australia, which is the world's leading producer of coking coal, can, to some extent, affect the situation in the global market. The coronavirus epidemic caused the introduction of temporary transportation restrictions to stop the spread of the virus, which affects the volume and speed of deliveries.

\section{CONCLUSION}

Mongolia has high-quality coal resources that are in demand at the global coal market. The coal consumption forecast made by international organizations for the potential importers of Mongolian coal is favorable for the intensive development of coal export from Mongolia.

Mongolia can enter the wider international coal market only through the ports of China or Russia. There are restrictions caused not only by the state of the Mongolian transportation infrastructure but also by the throughput capacity of Chinese and Russian railways from the Mongolian border to coal shipping ports and port facilities. Russia and China cannot always offer Mongolia favorable coal transportation conditions. Russian coal companies exporting coal through the ports of the Far East are not interested in the appearance of a competitor in the NEA market, which may affect tariffs in the coal shipping terminals controlled by them.

Prospects for the development of coal export depend on the state of the transportation and production infrastructure; opportunities to increase exploration work; development potential of domestic and foreign coal markets; geopolitical conditions limiting coal consumption; Russia and China's policies on the organization of transportation corridors to seaports to allow Mongolian coal to enter the NEA markets; the availability of investment, including foreign one for the implementation of projects. International companies participate in the development and implementation of projects related to the development of coal deposits and coal supplies for export, which has a positive effect on the development of the coal industry in Mongolia.

The state policy of Mongolia is aimed at supporting the development of the coal industry in various areas, including cooperation with international organizations; attraction of domestic and foreign investors; creation of a free market mechanism - deregulation of coal pricing; training skilled labor, and others.
In this situation, it seems important to direct the joint efforts of Mongolia, Russia, and China to develop measures to ensure the competitiveness of coal through integrated processing.

The capacity of the international coal market for Mongolian coal will remain favorable. Mongolia is already competing with the world's leading coal exporters, so far only with those exporting coal to China. In the future, under favorable conditions, Mongolia may become one of the main coal exporters to the countries of NEA.

The study was funded by the international grant of the Russian Foundation for Basic Research (project No. 18-510-94006) and the Ministry of Education, Culture, Science, and Sport of Mongolia (project No. ShuGh / OKhU / 2018/26)

\section{REFERENCES}

[1] Gotov Dugerjav, Enhancing Northeast Asia and Mongolia Economic Cooperation through Developing Transport Corridors. [Online]. Available: http://www. cscap.org/uploads/docs/Related\%20Research/10Gen Conf/7GotovDugerjav(Mongolia)10GC.pdf)

[2] Mongolian Statistical Information Service www.1212. $\mathrm{mn}$

[3] Vorobiov B.M. Coal of the World / Edited by L.A. Puchkova. - M.: Publishing House "Mountain Book", 2013, v.III; Coal of Eurasia. 752 p.

[4] Plakitkina L.S., Plakitkin Yu.A. The coal industry of the world and Russia: analysis, trends, and development prospects / - M.: Literature, 2017. - 374 p.

[5] Key world energy statistics. IEA 2019 -81 p. [Online]. Available: http://www.iea.org/statistics/

[6] BP Statistical Review of World Energy June 2018 [Online]. Available: https://nangs.org/analytics/bpstatistical-review-of-world-energy

[7] Ochirbat Punsalmaagiin. The coal industry of Mongolia: state and development prospects // Notes of the Mining Institute. 2017.v. 226. pp. 420-427. DOI: 10.25515/PMI.2017.4.420

[8] Status and Challenges to Coal Industry for Sustainable Development in North-East Asia and Identification of Opportunities for Subregional Cooperation in the Coal Sector: Intergovernmental Cooperation in Northeast Asia, Joint Study, Working Group on Coal /Melentiev Energy Systems Institute Of Siberian Branch of Russian Academy of Sciences, Moscow Irkutsk, 2011. - 146 p.

[9] Mongolian statistical yearbook. Edited by $\mathrm{S} /$ Mendsaikhan, G. Gerelt-Od, B. Erdenesuren, Kr. Bajiikhun, UlaanBaatar, 2015. 413 p.

[10] Yeren-Ulzii, Energy statistics, and trade of Mongolia for 2016 country report, 2016 Joint Study Expert Workshop 13 April 2017, Seoul. -17 p. 
[11] UN Comtrade Database [Online]. Available: https:// comtrade.un.org/data/

[12] Mongolia and coal [Online]. Available: https://www. gem.wiki/Mongolia_and_coal

[13] The annual report 2016, geology mining petroleum heavy industry [Godovoy otchet 2016, geologiya dobychi nefti, tyazhelaya promyshlennost'] Mineral resources and petroleum authority of Mongolia, Ulaanbaatar, 2017, 148 p. Ru.

[14] Coking Coal Industry Chain Summit, Report «Aspire Mining LLC», July 2011,QINGDAO, China. [Online]. Available: https://www.aspiremininglimited.com/ userfiles/file/267_20110707\%20coking\%20coal\%20 industry $\% 20$ chain $\% 20$ summit $\% 20$ presentation.pdf

[15] Ovoot coking coal project [Online]. Available: https:// aspiremininglimited.com/ovoot-coking-coal-project/)

[16] Sereeter Jigjee, Odgerel Ulziikhutag, Transport challenges and opportunities for Mongolia, 2018, 20 p. [Online]. Available: http://www.unescap.org/sites/ default/files/11\%20Mongolia.pdf)

[17] Key parameters of the largest specialized coal port terminals in the world / Expert Online. Moscow, 10.03.2020 [Online]. Available: https:/expert. ru/ratings/klyuchevyie-parametryi-krupnejshihspetsializirovannyih-ugolnyih-portovyih-terminalovv-mire/ Ru.

[18] Mongolian business [Online]. Available: https:// krasugol.ru/novosti/452-biznes-po-mongolski)

[19] Southern Mongolia Infrastructure Strategy/ The International Bank for Reconstruction and Development / The World Bank. -138 p. [Online]. Available: https://siteresources.worldbank.org/ INTMONGOLIA/Resources/SMIS_July.pdf

[20] Rygzynov T. Sh., Batomunkuev V.S., Luvsanzhantsangiin Erdenebayar. Development of the transportation infrastructure of Mongolia under a modern transformation of the economy / Mathematical and Instrumental Methods of Economics / MES, 11/2015 [Online]. Available: http:/uecs.ru/uecs-83-832015/item/3786-2015-1103-08-18-39?pop=1\&tmpl=component\&print=1

[21] Namsray Namjildorzh Intensification of cargo transportation through the network of JSC "Ulan-Bator Railway" for 2020 [Intensifikatsiya perevozok gruzov po seti AO«Ulan-Batorskaya zheleznaya doroga» na 2020 god] Sovremennye tekhnologii. Sistemnyi analiz. Modelirovanie [Modern Technologies. System Analysis. Modeling], 2018, No. 4 (60), pp. 132-138. Ru.

[22] Ulziinorov Gansukh, Xu Ming, Syed Ahtsham All Analysis of the Current Situation of Mongolian Railway and Its Future [Ves' analiz sovremennogo sostoyaniya zheleznoy dorogi Mongolii i yeye budushchego] Development International Business Research. -vol. 11, no. 5. pp.119-128 -2018 ISSN 1913-9004 E-ISSN 1913-9012. Ru.

[23] Bayasgalan Davaaseren Transit transportation of oil and gas processing products through the territory of Mongolia [Tranzitnyye perevozki produktsii nefte i gazopererabotki cherez territoriyu Mongolii] Sovremennye tekhnologii. Sistemnyi analiz. Modelirovanie [Modern Technologies. System Analysis. Modeling], 2018, no. 2 (58), pp. 64-72. Ru.

[24] Bayasgalan Davaaseren Justification for the construction of a second railway line between Mongolia and China [Obosnovaniye neobkhodimosti stroitel'stva vtoroy zheleznodorozhnoy linii mezhdu Mongoliyey i Kitayem] Sovremennye tekhnologii. Sistemnyi analiz. Modelirovanie [Modern Technologies. System Analysis. Modeling], 2018, No. 4 (60), pp. 56-63. Ru.

[25] The concept of implementing a joint RussianMongolian project for the development of JSC 'UBTZ' and the construction of new railway infrastructure in Mongolia [Kontseptsiya realizatsii sovmestnogo rossiysko-mongol'skogo proyekta razvitiya $\mathrm{AO}$ "UBTZ" i stroitel'stva novoy zhelezno-dorozhnoy infrastruktury v Mongolii] [Online]. Available: http:// www.rzd.ru/main/public/ru/accessible). Ru.

[26] Ana-Maria Seman MONGOLIA'S ENERGY SECTOR: time for a rethink APRIL 2017, 40 p. [Online]. Available: https://bankwatch.org/wpcontent/uploads/2017/06/Mongolia-energy-sectorweb.pdf

[27] BP Energy Outlook: 2019, 14 February 2019, [Online]. Available: https://www.bp.com/content/dam/bp/ business-sites/en/global/corporate/pdfs/news-andinsights/press-releases/bp-energy-outlook-2019.pdf

[28] International Energy Outlook 2017, September 14, 2017, U.S. Energy Information Administration, [Online]. Available: www.eia.gov/ieo

[29] Annual Energy Outlook 2019 with projections to 2050, January 24, 2019, U.S. Energy Information Administration, [Online]. Available: www.eia.gov/ ieo,www.eia.gov/aeo

[30] World Energy Outlook 2018, Flagship report - November 2018, U.S. Energy Information Administration, [Online]. Available: https://www.iea. org/reports/world-energy-outlook-2018, http://www. mongolnow.com/hoshoot-krupnejshee-ugolnoemestorozhdenij-v-azii/ 


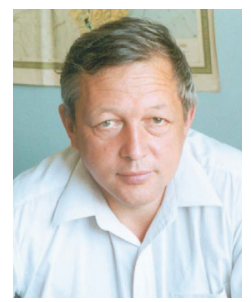

Alexander Sokolov received D. Sc. degree in engineering from the Melentiev Energy Systems Institute of the Siberian Branch of the Russian Academy of Sciences in 2006. Currently, he is a chief researcher and the head of the Laboratory of the Energy Sector of Siberia and the Far East at the Melentiev Energy Systems Institute SB RAS. His research interests include the studies and modeling of the development prospects of the energy sector industries.

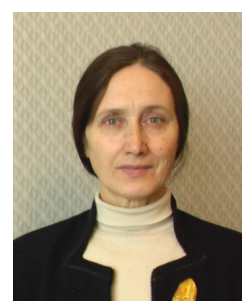

Liudmila Takaishvili received her $\mathrm{Ph} . \mathrm{D}$. degree in engineering from the Melentiev Energy Systems Institute of the Siberian Branch of the Russian Academy of Sciences in 1991. Currently, she is a senior researcher at the Melentiev Energy Systems Institute SB RAS. Her research areas include the studies of the coal industry development prospects and the development of software and information support for these studies.

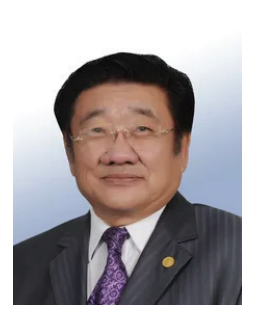

Ochirbat Punsalmaagiin, Doctor of Economic Sciences, Academician of the Academy of Sciences of Mongolia, Counselor, professor at Mining Institute of the Mongolian State University of Science \& Technology, Ulaanbaatar, Mongolia. His research interests include the development strategy of the mineral and raw materials complex and sustainable development of the mining industry. 